\title{
SOCIALLY RESPONSIBLE INVESTMENT (SRI) ATTITUDE OF MUTUAL FUND INVESTORS IN KARNATAKA
}

Babu K. A.

Dr. Giridhar K. V.

\begin{abstract}
:
Primary objective of the paper - The research intends to analyze the influence of various demographic and other factors on the attitude of selected mutual fund investors towards socially responsible investment avenues.
\end{abstract}

Methodology adopted -A well-structured questionnaire was used as a tool for the purpose of collecting the data required for the research. The sample size of 100 mutual fund investors is selected from Davanagere and Chitradurga districts of Karnataka state. The respondents are selected on random basis from the target population and also the area. The descriptive research design is adopted in this research.

Major findings of the paper- Majority of the respondents are male and also falling in the age group of $51-60$ years. It is found from the research that the age of the respondents has the considerable association with the factors considered for the investment decision. But the gender, educational qualification and the monthly income of the mutual fund investors has no relationship with the criteria for their investment decision.

Key-words: Socially Responsible Investment, attitude, mutual fund, investors and demographic factors.

Paper type - Research paper

\section{INTRODUCTION:}

Normally investors tend to invest in those mutual funds which offer higher rate of returns. But the mutual fund schemes which invest their funds in the companies which are 


\section{K.A. \& Dr. Giridhar K.V. / Page 131-147}

engaged in environmentally and socially favorable business operations face a challenge in attracting investment from the people who only expect better return from their investment. But still we can find some people who are environmentally and socially concerned would park their savings in the mutual fund schemes which would invest their funds in companies engaged in best business practices.

Socially Responsible Investment is the practice of parking savings by an individual, in companies and funds that have positive social impacts. It discourages investments in those companies which manufacture or dispose addictive products such as, alcohol, tobacco etc. It encourages investment in companies which are involved in social justice, environmental sustainability and alternative energy efforts etc. socially responsible investment has two important objectives such as achieving social good and also financial benefit in terms of return on investment. SRI does not mean that it guarantees return on the capital invested, but it gives the satisfaction to the investor of contributing to the betterment of the society. This investment is also understood as ethical and green investing. This also includes companies which are conscious about their employees, environment fairly and promote ethical policies.

\section{General goals of Socially Responsible Investors}

Below mentioned are the common goals set by the socially responsible investors for overall good of the society in which he lives.

- Achieving cleaner environment:The main goal of the investor is to see the cleaner environment leading to healthy environment. Hence, the government of India presently encourages the companies which do not normally pollute the environment in order to achieve Swatch Bharath vision. Hence the individual investors also can contribute in the Swatch Bharath movement of the government, at least indirectly by investing their savings in a mutual fund scheme, which in turn invests funds in a company which is producing and selling environmental friendly products.

- Offer social justice: Investors investing with the feeling of social responsibility must also have the goal of seeking social justice in the society. Social justice can even be in the way of selling products at reasonable prices, so that the people 


\section{K.A. \& Dr. Giridhar K.V. / Page 131-147}

from all class of the society can afford. Investor can also be the key in achieving social justice through investing their money in such companies which strive to maintain social justice.

- Fostering peace among the people of the society:Peaceful society can always achieve greater things. Investor can become the cause in promoting peace in the society by not investing his money in those funds or companies which are indulged in the production and sale of anti-social products, such as alcohol, tobacco products etc.

- Promoting health:These days, human beings are very conscious about their health. Most of the people spend major portion of their earning in order to safeguard themselves from diseases and also to maintain their health intact. Presently the whole world is facing the COVID-19 pandemic and there needs to be lot of investment of funds in those companies which are involved in the process of research in order to discover the vaccine. Similarly, there are many health issues the people living in the society are facing in the present days. Hence the individuals must invest lot of their money in those pharmaceutical companies, so that the investor can earn fairly good return and can also have the satisfaction of contributing in the process of promoting health of the people.

- Encouraging morality:Socially responsible investment not only promotes social justice, peace and health among the people of the society, it also promotes morality in conducting business activities. Morality is not only being reasonable in charging prices on the products and services, but also in all the phases of marketing their products and services in the society. Investors with SRI urge always search for those funds/companies promoting morality, in investing their money.

\section{Role of an investor participating in SRI process:}

Investors who invest their saving in socially responsible funds or companies play an important role. They are expected to perform the following important functions in the process of achieving the social cause. 


\section{K.A. \& Dr. Giridhar K.V. / Page 131-147}

- Identify the difference between positive and negative:Investor, who wishes to invest his hard earned money with the objective of achieving both the intention of earning fairly reasonable return on the invested capital and also achieve the gratification of contributing money to the good cause of the society, must always screen the companies and funds with their positive and negative impacts on the society. They must first recognize the difference between traditional and social conscious investment. If an investor invests only with the return as a criteria for judging between good and bad company, it is difficult for an investor to draw a line between traditional and SRI. The return from this investment naturally differs from traditional investment. An investor should primarily keep in mind the reason for his investment before screening the companies for taking investment decision. If his priority is to earn higher return, he cannot think of investing in SRI alternatives.

- Conduct a thorough research:An individual must be a researcher before making investment decision of their savings. He must study the financial market and find out which companies have social impact and which are not. If he thinks that he has already invested his savings in a company which is lacking social values or following business practices without social concern, he must take a decision of withdrawing his money and decide to invest in socially responsible companies.

- Exercise influence as an investor:Investors must try to influence their companies to invest their capital in companies possessing social consciousness. Shareholders must always offer their suggestions to the management of the company in which they invest their capital, to always move in a responsible way in the venture of conducting their business activities.

- Lead by examples:Individuals who participate in the SRI process must always lead others by always setting an example. For example, investing savings in only from those companies which make use of local resources and local labour in their production process is also a SRI practice. In that manner, an investor should lead others by being an example.

- Decide self-social principles:Every investor will not have ability or willingness to participate in SRI practices. For that one needs to decide his own social principles to possess such attitude of showing concern about the society besides 


\section{K.A. \& Dr. Giridhar K.V. / Page 131-147}

earning return on his investment. Such social principles can only lead them towards investing their savings in socially responsible funds.

- Selecting funds meeting investor's goals: Finally, in order to be successful in the movement of participating in the SRI practice, investor needs to select the best funds or companies for the purpose of investing their saved money, so that the investor can meet his goals of both earning the returns and also contributing money for the social betterment.

\section{REVIEW OF LITERATURE:}

It is found that many research studies have been carried out on the concept of socially responsible investment.Few of the important research studies which are carried out earlier on the proposed topic are reviewed and elucidated below:

Ankita Nagpal and Mansi Chadha (2020) has attempted to analyze the influence of various demographic factors on the perception of investors about the risk and return with regard to ethical and socially responsible mutual fund investments when compared to traditional mutual fund schemes. It is found from the study that the age and qualification of the investors has no influence on their purchase decision of Socially Responsible Investment (SRI) funds. But the gender of the respondents has no influence on their risk and return with regard to ethical mutual fund schemes.

Sally Ziad Alkees and Pr Latifa Ghalayini (2020) conducted a research study in order to investigate the effect of various factors on the social responsible investments in Lebanon. Outcomes of the research showed that the concept of social responsible investment is still in the beginning stage.

Suzette Viviers and Gideon Els (2017) carried out a research for the purpose of finding out important events which have changed the Responsible Investment (RI) market from 1992 to 2014, analyzing the criteria and strategies adopted by RI fund managers while investing their funds, and also to assess the ethical considerations of local funds in their RI process. 


\section{K.A. \& Dr. Giridhar K.V. / Page 131-147}

Anjum Ubaid Siddiqui (2018) conducted a study with the objective of analyzing the influence of demographic factors on socially responsible investors across different countries and time period, with the help of available literature. The findings of the study proved that Africa, South America and Asia are the countries which are totally underresearched. It is also found out that SR investors are heterogeneous group of people. Although there are various studies in different countries, it was difficult for the researcher to conclude about the features of SR investors.

Frank A.J. et al, (2013) carried out a research for the purpose of identifying various motives behind SRI and various parties involved in SRI. The study also attempts to assess the effectiveness of SRI on the performance of public companies in the changing social, environmental and corporate governance system.

Saiful Arefeen (2019) conducted a study to assess the performance and capacity of recovering from two economic shocks by socially responsible and also conventional funds which are listed in the Japan Investment Trust Association (JITA). It is found from the findings of the research that socially responsible funds were highly resilient compared to conventional funds.

Research Gap: SRI is the topic of interest in the country like India. But there is no much research on the attitude of mutual fund investors, to assess their attitude towards SRI, particularly in Karnataka state, and also in the districts selected for the research.

\section{STATEMENT OF THE PROBLEM:}

Normally investors think of investing their savings in those investment options, which will offer higher rates of return on the amount invested by them. But still we can find some of the investors who not only think of what is their benefit from investment, in terms of returns, but also showcase their concern towards the society. They will choose investment options which will have a positive social impact. Hence this research study attempts to answer the following questions: 


\section{K.A. \& Dr. Giridhar K.V. / Page 131-147}

(a) What factors influence the mutual fund investors on their Socially Responsible Investment attitude? And

(b) What is the relationship between various demographic factors and the factors considered for making investment decisions by mutual fund investors?

\section{OBJECTIVES OF THE STUDY:}

The research paper mainly aimed at knowing the attitude of mutual fund investors towards Socially Responsible Investment. Below mentioned are the other objectives of the research:

$>$ To find out different factors/criteria considered by the mutual fund investors in their investment process.

$>$ To find out the association between various demographic factors and criteria adopted by investors in their investment decisions.

\section{HYPOTHESES OF THE STUDY:}

Following are the hypotheses established and tested in this research study:

$\mathrm{H}_{01:}$ There is no significant association between the age of the respondents and the criteria for their investment decision.

$\mathrm{H}_{02}$ :There is no significant association between the Gender of the respondents and the criteria for their investment decision.

$\mathrm{H}_{03}$ :There is no significant relationship between the educational qualification of the respondents and the criteria for their investment decision.

$\mathrm{H}_{04}$ :There is no significant association between the monthly income of the respondents and the criteria for their investment decision.

\section{RESEARCH METHODOLOGY:}

The study is basically empirical one, based on data gathered from both primary and also from secondary sources. The respondents were the investors from Davanagere and Chitradurga Districts of Karnataka state.

- Primary Data: A structured questionnaire was applied as a tool to collect primary data from the sample rural households. 


\section{K.A. \& Dr. Giridhar K.V. / Page 131-147}

- Secondary Data: Secondary data have been collected from various books, journals and websites.

- Sample Size: Since the population under consideration is very large, the data are collected from only 100 investors from Davanagere and Chitradurga districts of Karnataka state.

- Sampling technique: The sampling procedure adopted under this study is Nonprobability convenient sampling.

\section{LIMITATIONS OF THE STUDY:}

The research is not free from limitations. Following are the limitations in this research study:

- The sample size of the study is very small and it is limited only to mutual fund investors.

- The study is restricted to only two districts in the state of Karnataka.

- Information provided by the respondents may not be reliable.

\section{DATA ANALYSIS AND INTERPRETATION:}

\section{Hypothesis No.1:}

H01: There is no significant relationship between the age of the respondents and the criteria for their investment decision

Table - 1: Age of the respondents and criteria for their investment decision

\begin{tabular}{|l|c|c|c|c|c|c|}
\hline \multirow{2}{*}{$\begin{array}{c}\text { Criteria for } \\
\text { investment decision }\end{array}$} & \multicolumn{5}{|c|}{ Age of the respondents (Years) } & TOTAL \\
\cline { 2 - 7 } & Below 30 & $\mathbf{3 0 - 4 0}$ & $\mathbf{4 1 - 5 0}$ & $\mathbf{5 1 - 6 0}$ & Above 60 & \\
\hline Return on Investment & 05 & 06 & 10 & 12 & 04 & $\mathbf{3 7}$ \\
\hline $\begin{array}{l}\text { Impact of investment } \\
\text { on the society }\end{array}$ & 01 & 03 & 05 & 08 & 03 & $\mathbf{2 0}$ \\
\hline $\begin{array}{l}\text { Environmental effect } \\
\text { of investment }\end{array}$ & 02 & 02 & 03 & 05 & 05 & $\mathbf{1 7}$ \\
\hline Previous & 03 & 05 & 07 & 05 & 06 & $\mathbf{2 6}$ \\
\hline
\end{tabular}


Towards Excellence: An Indexed, Refereed \& Peer Reviewed Journal of Higher Education / Babu

K.A. \& Dr. Giridhar K.V. / Page 131-147

\begin{tabular}{|c|c|c|c|c|c|c|}
\hline $\begin{array}{l}\text { performance of the } \\
\text { investment }\end{array}$ & & & & & \\
\hline TOTAL & $\mathbf{1 1}$ & $\mathbf{1 6}$ & $\mathbf{2 5}$ & $\mathbf{3 0}$ & $\mathbf{1 8}$ & $\mathbf{1 0 0}$ \\
\hline
\end{tabular}

Source: Survey data.

Calculation of Chi-square $\left(\chi^{2}\right)$

\begin{tabular}{|c|c|c|c|c|}
\hline $\begin{array}{c}\text { Observed } \\
\text { value } \\
\text { (O) }\end{array}$ & $\begin{array}{c}\text { Expected Value } \\
\text { (E) }\end{array}$ & $(\mathrm{O}-\mathrm{E})$ & $(\mathrm{O}-\mathrm{E})^{2}$ & $\frac{(\mathrm{O}-\mathrm{E})^{2}}{\mathrm{E}}$ \\
\hline 5 & 4.07 & 0.93 & 0.865 & 0.21 \\
\hline 6 & 5.92 & 0.08 & 0.006 & 1.01 \\
\hline 10 & 9.25 & 0.75 & 0.563 & 0.06 \\
\hline 12 & 11.10 & 0.90 & 0.810 & 0.07 \\
\hline 4 & 6.60 & -2.60 & 6.760 & 1.02 \\
\hline 1 & 2.20 & -1.20 & 1.440 & 0.65 \\
\hline 3 & 3.20 & -0.20 & 0.040 & 0.01 \\
\hline 5 & 5.00 & 0.00 & 0.000 & 0.00 \\
\hline 8 & 6.00 & 2.00 & 4.000 & 0.67 \\
\hline 3 & 3.60 & -0.60 & 0.360 & 0.10 \\
\hline 2 & 1.87 & 0.13 & 0.017 & 9.09 \\
\hline 2 & 2.72 & -0.72 & 0.518 & 0.19 \\
\hline 3 & 4.25 & -1.25 & 1.562 & 0.37 \\
\hline 5 & 5.10 & -0.10 & 0.010 & 1.96 \\
\hline 5 & 3.06 & 1.94 & 3.764 & 1.23 \\
\hline 3 & 2.86 & 0.14 & 0.019 & 6.64 \\
\hline 5 & 4.16 & 0.84 & 0.705 & 0.17 \\
\hline 7 & 6.50 & 0.50 & 0.250 & 0.04 \\
\hline
\end{tabular}


Towards Excellence: An Indexed, Refereed \& Peer Reviewed Journal of Higher Education / Babu

K.A. \& Dr. Giridhar K.V. / Page 131-147

\begin{tabular}{|c|c|c|c|c|}
\hline 5 & 7.80 & -2.80 & 7.840 & 1.00 \\
\hline 6 & 4.68 & 1.32 & 1.742 & 0.37 \\
\hline \multicolumn{4}{|c|}{ Chi -Square Value } & $\mathbf{2 4 . 8 6}$ \\
\hline
\end{tabular}

Interpretation of the results:

The above table shows that the chi-square tests of age and the criteria for investment decision of the respondents. The calculated Pearson Chi-square value is 24.86 at 0.05 level of significance, which is greater than the table value (critical value) $21.03(\mathrm{df}=12)$. Therefore it can be concluded that the null hypothesis is rejected, and alternative hypothesis is accepted. Therefore, it can be stated that there is a significant relationship between the age of the respondents and the criteria adopted by them for their investment decision making.

\section{Hypothesis No.2:}

Ho2: There is no significant association between the Gender of the respondents and the criteria for their investment decision.

Table - 2: Gender of the respondents and Criteria for Investment decision

\begin{tabular}{|c|c|c|c|}
\hline \multirow{2}{*}{ Criteria for investment decision } & \multicolumn{2}{|c|}{ Gender } & \multirow[t]{2}{*}{ TOTAL } \\
\hline & Male & Female & \\
\hline Return on Investment & 27 & 15 & 42 \\
\hline Impact of investment on the society & 09 & 04 & 13 \\
\hline Environmental effect of investment & 13 & 03 & 16 \\
\hline Previous performance of the investment & 19 & 10 & 29 \\
\hline TOTAL & 68 & 32 & 100 \\
\hline
\end{tabular}

Source: Survey data

Calculation of Chi-square $\left(\chi^{2}\right)$

\begin{tabular}{|c|c|c|c|c|}
\hline $\begin{array}{c}\text { Observed } \\
\text { value } \\
(\mathbf{O})\end{array}$ & $\begin{array}{c}\text { Expected Value } \\
(\mathbf{E})\end{array}$ & $(\mathbf{O}-\mathbf{E})$ & $(\mathbf{O}-\mathbf{E})^{\mathbf{2}}$ & $(\mathbf{O}-\mathbf{E})^{\mathbf{2}}$ \\
\hline 27 & 28.56 & -1.56 & 2.43 & $\mathbf{E}$ \\
\hline
\end{tabular}


Towards Excellence: An Indexed, Refereed \& Peer Reviewed Journal of Higher Education / Babu

K.A. \& Dr. Giridhar K.V. / Page 131-147

\begin{tabular}{|c|c|c|c|c|}
\hline 15 & 13.44 & 1.56 & 2.43 & 0.18 \\
\hline 09 & 8.84 & 0.16 & 0.03 & 0.00 \\
\hline 04 & 4.16 & -0.16 & 0.03 & 0.01 \\
\hline 13 & 10.88 & 2.12 & 4.49 & 0.41 \\
\hline 03 & 5.12 & -2.12 & 4.49 & 0.88 \\
\hline 19 & 19.72 & -0.72 & 0.52 & 0.03 \\
\hline 10 & 9.28 & 0.72 & 0.52 & 0.06 \\
\hline \multicolumn{5}{|c|}{ Chi-Square Value } \\
\hline
\end{tabular}

\section{Interpretation:}

The above table shows that the chi-square tests of Gender of the respondents and the criteria for their investment decision. The calculated Pearson Chi-square value is 1.65 at 0.05 level of significance, which is less than the table value (critical value) $7.81(\mathrm{df}=3)$. Therefore, it can be concluded that the null hypothesis is accepted. Hence it can be concluded that there is no significant relationship between the gender of the respondents and the criteria adopted by them for their investment decision making.

\section{Hypothesis No.3:}

Ho3: There is no significant relationship between the educational qualification of the respondents and the criteria for their investment decision.

Table - 3: Educational Qualification of the respondents and criteria for investment decision

\begin{tabular}{|c|c|c|c|c|c|c|}
\hline \multirow{2}{*}{$\begin{array}{c}\text { Criteria for } \\
\text { investment decision }\end{array}$} & $\begin{array}{c}\text { Upto } \\
\mathbf{1 0}^{\text {th }} \text { Std }\end{array}$ & $\begin{array}{c}\text { Upto } \\
\mathbf{1 2}^{\text {th }} \text { Std }\end{array}$ & $\begin{array}{c}\text { Bachelor's } \\
\text { Degree }\end{array}$ & $\begin{array}{c}\text { Master's } \\
\text { Degree }\end{array}$ & Other & \\
\hline Return on Investment & 05 & 07 & 11 & 06 & 07 & 36 \\
\hline Impact of investment & 02 & 03 & 05 & 03 & 03 & 16 \\
\hline
\end{tabular}


Towards Excellence: An Indexed, Refereed \& Peer Reviewed Journal of Higher Education / Babu

K.A. \& Dr. Giridhar K.V. / Page 131-147

\begin{tabular}{|l|c|c|c|c|c|c|}
\hline on the society & & & & & & \\
\hline $\begin{array}{l}\text { Environmental effect } \\
\text { of investment }\end{array}$ & 01 & 04 & 07 & 04 & 02 & 18 \\
\hline $\begin{array}{l}\text { Previous performance } \\
\text { of the investment }\end{array}$ & 04 & 05 & 08 & 09 & 04 & 30 \\
\hline \multicolumn{1}{|c|}{ TOTAL } & $\mathbf{1 2}$ & $\mathbf{1 9}$ & $\mathbf{3 1}$ & $\mathbf{2 2}$ & $\mathbf{1 6}$ & $\mathbf{1 0 0}$ \\
\hline
\end{tabular}

Source: Survey data

Calculation of Chi-square $\left(\chi^{2}\right)$

\begin{tabular}{|c|c|c|c|c|}
\hline $\begin{array}{c}\text { Observed } \\
\text { value } \\
\text { (O) }\end{array}$ & $\begin{array}{c}\text { Expected Value } \\
\text { (E) }\end{array}$ & $(\mathbf{O}-\mathbf{E})$ & $(O-E)^{2}$ & $\frac{(\mathbf{O}-\mathbf{E})^{2}}{E}$ \\
\hline 5 & 4.32 & 0.68 & 0.462 & 0.107 \\
\hline 7 & 6,84 & 0.16 & 0.025 & 0.004 \\
\hline 11 & 11.16 & -0.16 & 0.025 & 0.002 \\
\hline 6 & 7.92 & -1.92 & 3.686 & 0.465 \\
\hline 7 & 5.76 & 1.24 & 1.537 & 0.267 \\
\hline 2 & 1.92 & 0.08 & 0.006 & 0.003 \\
\hline 3 & 3.04 & -0.04 & 0.002 & 0.001 \\
\hline 5 & 4.96 & 0.04 & 0.002 & 0.000 \\
\hline 3 & 3.52 & -0.52 & 0.27 & 0.077 \\
\hline 3 & 2.56 & 0.44 & 0.194 & 0.076 \\
\hline 1 & 2.16 & -1.16 & 1.345 & 0.623 \\
\hline 4 & 3.42 & 0.58 & 0.336 & 0.098 \\
\hline 7 & 5.58 & 1.42 & 2.016 & 0.361 \\
\hline 4 & 3.96 & 0.04 & 0.002 & 0.001 \\
\hline 2 & 2.88 & -0.88 & 0.774 & 0.269 \\
\hline 4 & 3.6 & 0.4 & 0.002 & 0.001 \\
\hline 5 & 5.7 & -0.7 & 0.49 & 0.086 \\
\hline 8 & 9.3 & -1.3 & 1.69 & 0.182 \\
\hline 9 & 6.6 & 2.4 & 5.76 & 0.873 \\
\hline
\end{tabular}


Towards Excellence: An Indexed, Refereed \& Peer Reviewed Journal of Higher Education / Babu

K.A. \& Dr. Giridhar K.V. / Page 131-147

\begin{tabular}{|l|l|l|l|l|}
\hline 4 & 4.8 & -0.8 & 0.64 & 0.133 \\
\hline \multicolumn{3}{|c|}{ Chi -Square Value } & $\mathbf{3 . 6 2 8}$ \\
\hline
\end{tabular}

Interpretation of the results:

The above table shows that the chi-square tests of Educational qualification of the respondents and the criteria for their investment decision. The calculated Pearson Chisquare value is 3.628 at 0.05 level of significance, which is less than the table value (critical value) $21.03(\mathrm{df}=12)$. Therefore the null hypothesis is accepted, and it can be concluded that there is no significant relationship between the educational qualification of the respondents and the criteria adopted by them for their investment decision making.

\section{Hypothesis No. 4:}

H04: There is no significant association between the monthly income of the respondents and the criteria for their investment decision.

Table - 4: Monthly income of the respondents and criteria for investment decision

\begin{tabular}{|l|c|c|c|c|c|c|}
\hline \multirow{2}{*}{$\begin{array}{l}\text { Criteria for investment } \\
\text { decision }\end{array}$} & \multicolumn{5}{|c|}{ Monthly Income (Rs.) } & TOTAL \\
\cline { 2 - 7 } & $\begin{array}{l}\text { Below } \\
\mathbf{2 0 , 0 0 0}\end{array}$ & $\begin{array}{c}\mathbf{2 0 , 0 0 0} \\
\mathbf{3 0 , 0 0 0}\end{array}$ & $\begin{array}{c}\mathbf{3 1 , 0 0 0}- \\
\mathbf{4 0 , 0 0 0}\end{array}$ & $\begin{array}{c}\mathbf{4 1 , 0 0 0}- \\
\mathbf{5 0 , 0 0 0}\end{array}$ & $\begin{array}{c}\text { Above } \\
\mathbf{5 0 , 0 0 0}\end{array}$ & \\
\hline Return on Investment & 02 & 07 & 16 & 13 & 07 & 45 \\
\hline $\begin{array}{l}\text { Impact of investment on the } \\
\text { society }\end{array}$ & 02 & 02 & 04 & 02 & 01 & 11 \\
\hline $\begin{array}{l}\text { Environmental effect of } \\
\text { investment }\end{array}$ & 01 & 02 & 03 & 03 & 02 & 11 \\
\hline $\begin{array}{l}\text { Previous performance of } \\
\text { the investment }\end{array}$ & 03 & 05 & 12 & 09 & 04 & 33 \\
\hline \multicolumn{1}{|c|}{ TOTAL } & $\mathbf{0 8}$ & $\mathbf{1 6}$ & $\mathbf{3 5}$ & $\mathbf{2 7}$ & $\mathbf{1 4}$ & $\mathbf{1 0 0}$ \\
\hline
\end{tabular}

Source: Survey data

\section{Calculation of Chi-square $\left(\chi^{2}\right)$}

\begin{tabular}{|c|c|c|c|c|}
\hline $\begin{array}{c}\text { Observed } \\
\text { value } \\
(\mathbf{O})\end{array}$ & $\begin{array}{c}\text { Expected Value } \\
(\mathbf{E})\end{array}$ & $(\mathbf{O}-\mathbf{E})$ & $(\mathbf{O}-\mathbf{E})^{\mathbf{2}}$ & $(\mathbf{O}-\mathbf{E})^{\mathbf{2}}$ \\
\hline 2 & 3.6 & -1.6 & 2.56 & $\mathbf{E}$ \\
\hline 7 & 7.2 & -0.2 & 0.04 & 0.7111 \\
\hline 16 & 15.75 & 0.25 & 0.062 & 0.0039 \\
\hline
\end{tabular}


Towards Excellence: An Indexed, Refereed \& Peer Reviewed Journal of Higher Education / Babu

K.A. \& Dr. Giridhar K.V. / Page 131-147

\begin{tabular}{|c|c|c|c|c|}
\hline 13 & 12.15 & 0.85 & 0.722 & 0.0594 \\
\hline 7 & 6.3 & 0.7 & 0.49 & 0.0778 \\
\hline 2 & 0.88 & 1.12 & 1.254 & 1.4250 \\
\hline 2 & 1.76 & 0.24 & 0.057 & 0.0324 \\
\hline 4 & 3.85 & 0.15 & 0.023 & 0.0060 \\
\hline 2 & 2.97 & -0.97 & 0.941 & 0.3168 \\
\hline 1 & 1.54 & -0.54 & 0.291 & 0.1890 \\
\hline 1 & 0.88 & 0.12 & 0.014 & 0.0159 \\
\hline 2 & 1.76 & 0.24 & 0.057 & 0.0324 \\
\hline 3 & 3.85 & -0.85 & 0.722 & 0.1875 \\
\hline 3 & 2.97 & 0.03 & 0.0009 & 0.0003 \\
\hline 2 & 1.54 & 0.46 & 0.212 & 0.1377 \\
\hline 3 & 2.64 & 0.36 & 0.129 & 0.0489 \\
\hline 5 & 5.28 & -0.28 & 0.078 & 0.0148 \\
\hline 12 & 11.55 & 0.45 & 0.202 & 0.0175 \\
\hline 9 & 8.91 & 0.09 & 0.008 & 0.0009 \\
\hline 4 & 4.62 & -0.62 & 0.384 & 0.0831 \\
\hline \multicolumn{4}{|c|}{ Chi -Square Value } & 3.366 \\
\hline
\end{tabular}

\section{Interpretation of the results:}

The above table shows that the chi-square tests of monthly income of the respondents and the criteria for their investment decision. The calculated Pearson Chi-square value is 3.366 at 0.05 level of significance, which is less than the table value (critical value) 21.03 $(\mathrm{df}=12)$. Therefore, it can be concluded that the null hypothesis is accepted. Hence it can be concluded that there is no significant association between the monthly income of the respondents and the criteria adopted by them for their investment decision making.

\section{FINDINGS OF THE STUDY:}

Following are the major finding of the research study: 


\section{K.A. \& Dr. Giridhar K.V. / Page 131-147}

Majority of the respondents fall in the age group between 51-60 years, and there is a relationship between the age of the mutual fund investors and the criteria adopted by them in their investment decision making process.

- Male respondents were 68 out of 100 respondents. Out of them 27 mutual fund investors consider return on investment as the criteria for their investment decision. It is proved from the analysis of the data that there is no association between the gender of the respondents and criteria for their investment decision.

* Majority of the mutual fund investors who were selected as sample respondents possess Bachelor's degree as their qualification, and it is found that educational qualification of the mutual fund investors has no relationship with the factor considered by them for their investment decision.

* Mutual fund investors in the monthly income category of Rs.31,000 to 40,000 are highest in number. Out of them majority of the investor treated return on investment as the criteria for their investment decision.

\section{RECOMMENDATIONS:}

* There is an urgent need to create awareness among the mutual fund investors to park their savings in Socially Responsible mutual fund schemes, which give importance to the social and environmental concern.

* Mutual fund schemes possessing both reasonable rate of return on investment along with social and environmental concern should be given special consideration in the tax laws of the government, in order to promote SRI.

\section{CONCLUSION:}

Socially Responsible Investment is a type of investment which will have both financial and non-financial goals. Non-financial goals may comprise of showing environmental concern, social concern and also considering moral values in the process of investment decision making. Normally SRIs refuse investment in those companies which will not have employment policies valuing human rights or companies which cause damage to environment in different ways, or damaging social values. SRI does not 


\section{K.A. \& Dr. Giridhar K.V. / Page 131-147}

mean that it guarantees return on the capital invested, but it gives the satisfaction to the investor of contributing to the betterment of the society. This investment is also understood as ethical and green investing. This also includes companies which are conscious about their employees, environment fairly and promote ethical policies. 


\section{K.A. \& Dr. Giridhar K.V. / Page 131-147}

\section{References}

1. Ankita Nagpal, and Mansi Chadha (2020), Investor's Perception on Ethical Investing/Socially Responsible Investment in Mutual Funds: with respect to Delhi. International Journal of Disaster Recovery and Business Continuity, 11(1), pp. 10671074.

2. Sally Ziad Alkees, and Pr Latifa Ghalayini (2020), Social Responsibility Investments in Lebanon. International Journal of Sciences: Basic and Applied Research, 53(2), pp. 211 229.

3. Suzette Viviers and Gideon Els (2017), Responsible investing in South Africa: past, present and future. African Review of Economic and Finance, 9(1), pp. 122-155.

4. Anjum Ubaid Siddiqui (2018), The Demography of Socially Responsible Investors across countries and Time: A Systematic Review. Asian Journal of Management Science, 7(2), pp.7-15.

5. Frank A.J. et al, (2013) The effectiveness of Socially Responsible Investment: A Review. Journal of Integrative Environmental Sciences, 10: 3-4, p.p. 235-252. DOI:10.1080/1943815X.2013.844169.

6. Saiful Arefeen (2019) Performance and resilience of Socially Responsible Investing (SRI) and conventional funds during different shocks in 2016: Evidence from Japan. DOI: $10.3390 /$ su12020540.

\section{Babu K. A. \\ Assistant Professor, Department of Commerce and Management Government First Grade College for Women, Davanagere Research scholar, Department of Commerce, Kuvempu University Karnataka \\ Cell No. 9945431055 E-Mail: babajang2006@gmail.com babajan23 mcom@yahoo.co.in}

$$
\boldsymbol{d}
$$

Dr. Giridhar K. V.

Assistant Professor, Department of commerce \& Management, Sahyadri

Commerce and Management College, Constituent College of Kuvempu

University Shivamogga

Cell No.9980647833, E-Mail: giridharmalnad@gmail.com 